Estudios Constitucionales, Año 9, No 1, 2011, pp. 245 - 276.

ISSN 0718-0195

Centro de Estudios Constitucionales de Chile Universidad de Talca

"Aproximación histórica al tratamiento jurídico y social dado a la homosexualidad en Europa"

María Martín Sánchez

\title{
APROXIMACIÓN HISTÓRICA AL TRATAMIENTO JURÍDICO Y SOCIAL DADO A LA HOMOSEXUALIDAD EN EUROPA ${ }^{1}$.
}

\author{
HISTORICAL APPROACH TO THE LEGAL AND SOCIAL TREATMENT \\ GIVEN TO HOMOSEXUALITY IN EUROPE)
}

María Martín SÁNCHeZ ${ }^{2}$

Profesora Doctora de Derecho Constitucional de la Universidad de Castilla-La Mancha

RESUMEN: La homosexualidad no es un fenómeno de reciente aparición, sino que ha estado presente en las más diversas sociedades y civilizaciones, en las que se le ha dado un trato muy diverso en función de diferentes factores. La propia experiencia revela que la diferente posición respecto a la homosexualidad, admitiéndose e incluso venerándose o llegándose a condenar penalmente, responde al grado de tolerancia de la sociedad en que se contextualice, sin obviar otras circunstancias. La evolución que ha experimentado ha logrado en la actualidad su protección juridica ante los más altos organismos europeos (TEDH), hasta lograr el reconocimiento del derecho al matrimonio homosexual en algunos paises como es el caso de España, Holanda o Bélgica.

ABSTRACT: Homosexuality is not a recent phenomenon, but it has been present in all societies and civilizations along History, being treated in many different ways depending on diverse factors. The experience reveals that the different attitudes towards homosexuality, from its acceptance or veneration to its criminal conviction, respond to each society's level of tolerance, without forgetting other circumstances. The evolution of homosexuality throughout History has currently achieved, not only its legal protection from discrimination in the highest European Organisms, such as the European Court of Human Rights (ECHR), but also the acknowledgement of same sex marriages in some countries, such as Spain, Holland or Belgium.

PALABRAS CLAVE: homosexualidad, tolerancia, represión, naturaleza, discriminación.

KEY WORDS: Homosexuality, tolerance, repression, nature, discrimination.

\footnotetext{
${ }^{1}$ Sobre el tema tratado en el presente trabajo puede consultarse la monografía siguiente: MARTín, M. (2008): Matrimonio homosexual y Constitución (Madrid, Tirant lo Blanch).

2 Profesora Contratada Doctora de Derecho Constitucional. Coordinadora del Doctorado en Derecho Constitucional Latinoamericano y Coordinadora del Curso de Postgrado en Derecho Constitucional para Iberoamericanos (Toledo), de la Universidad de Castilla-La Mancha, España. Doctora en Derecho Constitucional, por la Universidad de Castilla-La Mancha, Toledo, España. DEES y Experta en Derecho Europeo, por la Universidad de Montesquieu-Bordeaux IV, Francia. Licenciada en Derecho y DEA, por la Universidad de Castilla-La Mancha, Ciudad-Real y Toledo, España. Artículo recibido el 4 de agosto de 2010 y aprobado el 16 de marzo de 2011.
} 


\section{EXCURSO HISTÓRICO}

La homosexualidad no es algo nuevo que haya surgido en nuestra época, ni se trata de un asunto ni un problema que hemos de abordar desde cero, del que no se conozca nada. Se trata de un fenómeno que ha coexistido siempre en nuestras sociedades, aunque no de modo generalizado sino afectando directamente al individuo, por tratarse de escoger una orientación sexual diferente a la que escoge la mayoría de los individuos de su género. Ha costado siglos poder afirmar abiertamente que no es una enfermedad, que no es una perturbación ni un delito, aunque costará algunos más confirmar que no es pecado para la mayoría de las confesiones religiosas.

La homosexualidad ya se experimentaba en numerosos pueblos primitivos en los que se aceptaba sin ningún miramiento como una actitud sexual cotidiana. Son muchas las investigaciones antropológicas y sociológicas que se han hecho sobre diferentes sociedades humanas, para llegar a la conclusión de que en muchas de ellas se admitía la homosexualidad como un comportamiento sexual más.

Por lo tanto, parecen no encajar los argumentos dados a lo largo de la historia, basados en que la homosexualidad es pecado contra naturam, en el sentido de considerar que es contrario a la naturaleza humana, en consonancia con la cual sólo tienen cabida las relaciones de orden heterosexual para mantener la reproducción de la especie humana. Si así fuera estaríamos admitiendo que la humanidad, desde que existe, desde el principio de los tiempos en que se formaron las primeras sociedades primitivas se compone de individuos que per-se son pecadores, delincuentes, enfermos o depravados y pervertidos, en distinta escala según la época histórica por la que atraviesen, algo que sería irracional visto desde un prisma histórico.

Con la evolución histórica, también la concepción de la homosexualidad ha ido evolucionando considerablemente a través de los sucesivos pueblos, culturas y épocas que ha atravesado. Es necesario hacer un breve recorrido por dicha evolución para entender el alcance de la problemática homosexual y la necesidad de alcanzar la situación de tolerancia real y efectiva que sólo puede lograrse desde el derecho constitucional.

La intolerancia hacia la homosexualidad no es en modo alguno una situación exclusiva de los tiempos modernos. Como explican algunos historiadores, si bien es cierto que son sólo casos aislados, las culturas antiguas en las que se condenaban las relaciones homosexuales, éstos también existieron. Remontándonos a la Antigua Mesopotamia, se puede comprobar que entre sus pueblos, tal y como afirma la mayoría de los estudiosos, se encuentra una de las antiguas y conocidas leyes contra la sodomía ${ }^{3}$.

${ }^{3}$ GarCÍA (1981), p. 15. 
En el Antiguo Egipto, en cambio, las prácticas homosexuales eran admitidas. La civilización egipcia, caracterizada por el alto nivel de desarrollo que alcanzó, incluía frecuentemente las prácticas sodomíticas en sus cultos religiosos. Esto es una clara muestra de que las prácticas homosexuales, y todo lo relacionado con la homosexualidad ha preocupado a la humanidad desde siempre, en todas sus épocas y civilizaciones. Para el estudio de la situación y el tratamiento de las uniones homosexuales en culturas clásicas como la Antigua Grecia es preciso partir de la idea de que en aquel contexto, la homosexualidad nunca fue vista como una anormalidad frente a la heterosexualidad; más bien al contrario, fue vivida como una alternativa sexual.

A este respecto es importante tener en cuenta el papel de la mujer en la mentalidad de la antigüedad griega. La mujer estaba considerada como un ser inferior al hombre, incapaz incluso de poder proporcionarle placer sexual. Por ello, el sexo heterosexual, se practicaba como necesidad biológica o fisiológica, pero eran las relaciones homoeróticas con el amante ${ }^{4}$, el único medio para alcanzar realmente el placer y de obtenerlo entre iguales. No constituían pues los homosexuales un grupo catalogado como minoría y en cierta forma marginado, discriminado o desfavorecido -como ocurre en las sociedades actuales-, sino que la homosexualidad era considerada como una opción más de vida, sin darle mayor importancias. La razón de la "normalidad" con que era tratada la opción homosexual radica en la similitud que ofrecen la homosexualidad y la

${ }^{4}$ GonZÁlez (1976), p. 122

${ }^{5}$ Sergent (1986), p. 56. En opinión de Sergent -físico y antropólogo, autor relevante por sus estudios llevados a cabo en relación con la evolución histórica de la homosexualidad en las antiguas civilizaciones-, no sólo en la Antigua Grecia sino en el Mundo Indoeuropeo en general, abundan los mitos y rasgos culturales, procedentes de ritos y mitos iniciáticos. Así pues, la homosexualidad como rasgo cultural dominante, opuesto a las culturas de la civilización occidental actual, nacía en dichas sociedades frecuentemente a través del llamado "rito iniciático" o "institución iniciática"; esto es, la relación homosexual entre el maestro o "iniciador" y los candidatos a la iniciación, la cuál era además una relación socialmente obligatoria. Efectivamente, a nosotros, desde nuestra civilización occidental, oír hablar del rito iniciático puede resultarnos difícil de entender debido a la separación radical: homosexualidad/heterosexualidad que siempre hemos concebido. Sin embargo, no olvidemos que en la Antigua Grecia no existía esa separación radical. El rito iniciático no era un acto humillante a través del cual el maestro, por serlo, obligaba a someterse a él al joven porque la sociedad así se lo imponía. Al contrario, los señores de posición entre la sociedad, casados y bien situados, escogían a los púberes -jóvenes- mejor preparados de la ciudad para iniciarlos. No era un acto oculto y oscuro; a partir de la elección, el maestro -erasta- y su púber -erómeno- acudían juntos a actos públicos y era conocida su relación. A través del rito de la iniciación, el erasta iniciaba sexualmente a su erómeno, con lo cual el rito suponía la madurez biológica del erómeno. Sin embargo, el hecho de que se iniciara homosexualmente, no implicaba que fuera homosexual ya que se trataba sólo de iniciar su actividad sexual. Además, el rito consistía en adquirir la madurez como hombre, aprendiendo a luchar. Por ello el periodo de iniciación se desarrollaba en la campiña, tras el cual el iniciado alcanzaba su madurez biológica y física y así, estaba preparado para casarse y con el estatus de hombre adulto. 
heterosexualidad en aquellas sociedades, algo que choca frontalmente con el lugar que ocupa la heterosexualidad en sociedades de tradición judeo-cristiana, como la nuestra.

De este modo, en la cultura de la Antigua Grecia la homosexualidad era considerada una conducta normal. No era posible hacer discriminaciones ni minorías porque todos los hombres de posición practicaban el rito iniciático, es decir, se iniciaban homosexualmente para adquirir la madurez incluso antes de conocer su propia condición sexual ${ }^{6}$. No existía una separación absoluta y radical entre heterosexualidad y homosexualidad, como ocurre en nuestra sociedad, sino que se entendía la homosexualidad desde una tolerancia y normalidad difícil de encajar en sociedades de raíz judeo-cristiana.

El mismo espíritu de tolerancia hacia la homosexualidad imperó en la civilización de la Antigua Roma. Esto es lo que puede desprenderse de los textos latinos que nos han legado - gran fuente de información sobre la vida sexual en aquella época- , gracias a la tolerancia en que se vivió bajo el Imperio de Roma, donde las prácticas homosexuales estaban dentro de la legalidad. Esta tolerancia no debe sorprender en un Imperio donde algunos de los más grandes de sus emperadores ${ }^{7}$ pasaron a la posteridad con el mito de su condición homosexual $\mathrm{y}$ de quienes fueron harto conocidos sus amoríos con otros varones. No quiere decir esto que su condición fuese exclusivamente homosexual -en algunos sí-, sino que practicaban la homosexualidad de igual forma que mantenían relaciones heterosexuales.

Hacia el año 226 a. C. se aprobó la Lex Scantinia, que regulaba la práctica sexual, de la que no se ha conservado ningún texto, por lo que no existe modo de averiguar la materia que regulaba para dilucidar si incluía o no las prácticas homosexuales. En torno a dicha Ley han surgido voces que defienden arduamente la supuesta condena que en ella se hacía de la homosexualidad ${ }^{8}$. Sin embargo, parece bastante improbable que hubiera existido una ley de condena de la homosexualidad y hubiera sido desconocida por toda la sociedad, incluso por los grandes conocedores de Derecho romano -como Cicerón. Más aún, no tendría ninguna lógica encajar una ley de condena o prohibición a la homosexualidad en una sociedad en la que no sólo sus gobernantes practicaban la homosexualidad -aunque pudiera pensarse que ellos quedaban exentos del castigo-, sino que se ejercía legalmente la

\footnotetext{
${ }^{6}$ Brundage (2000), p. 34; Martínez (2005), p. 54.

${ }^{7}$ Boswell (1998), p. 99.

${ }^{8}$ BRUNDAGe (2000), p. 65.
} 
prostitución homosexual. Tal era la expansión de esta actividad que se gravó con impuesto y se concedían vacaciones legales a los que la ejercían?.

Este tipo de prácticas sexuales a través de relaciones esporádicas, haciendo uso de la prostitución, donde no aparece la palabra amor, destacan el lado libertino de esta cultura y contrastan con un amor homosexual más espiritual que también existió $^{10}$. De hecho, fruto de la existencia de estas relaciones homosexuales fuertes, basadas en el amor, surgió en Roma por primera vez el "matrimonio homosexual"11. Esta es una prueba más de la legalidad de las relaciones homosexuales en Roma, la existencia de leyes reguladoras de aspectos tan importantes como el régimen jurídico-legal de las uniones homosexuales, previstos como matrimonios. Esto es un precedente importantísimo en la historia para abordar la problemática actual, aunque sin olvidar que el contexto, la cultura y las circunstancias son completamente diferentes. En Roma, existían generalmente dos tipos de relaciones homosexuales: las uniones informales, dominantes en las clases bajas; y las uniones permanentes y exclusivas, propias de las clases altas y que culminaban en matrimonio -matrimonios homosexuales. Ésta es la primera vez en la historia que se habla formal y legalmente de "matrimonio homosexual" como vínculo matrimonial exacto al heterosexual, entre personas del mismo sexo. El matrimonio homosexual consistía en realizar una ceremonia nupcial entre dos hombres, celebrando el matrimonio según la misma ley reguladora del matrimonio entre hombre y mujer -sólo aparece reflejado el matrimonio homosexual entre varones por la discriminación a la que estaba sometida la homosexualidad femenina, la cual era prácticamente ignorada. Por ello, no se conocen matrimonios homosexuales entre mujeres. A modo de ejemplo, Nerón contrajo matrimonio legal siguiendo este rito, en dos ocasiones, con dos hombres distintos, en ceremonia pública.

Fue por primera vez en el siglo VI cuando el Derecho romano prohibió las relaciones homosexuales. A este respecto no han faltado quienes han visto en la

\footnotetext{
${ }^{9}$ Brundage (2000), p. 43; Boswell (1998), p. 93; Martinez (2005), p. 58.

${ }^{10}$ Martinez (2005), p. 51; Boswell (1998), p. 108. En su opinión, algunos modelos de este amor fiel y profundo fueron: Escolpio y Gitón y, sobre todo, los amantes por excelencia, el emperador Adriano y Antínoo -a quien deificó tras su muerte y se mantuvo fiel a su amor por él.

${ }^{11}$ Boswell (1998), p. 94; BosWell (1996), p. 223. En opinión de este autor, puede afirmarse la existencia de este tipo de matrimonios en Roma, caracterizados por su estatus inferior. Sostiene la celebración de "uniones del mismo sexo" por parte de la propia Iglesia, durante la Edad Media. Para ello, se vale de manuscritos medievales y textos litúrgicos. Además, sustenta su teoría principalmente en la celebración de las denominadas ceremonias de "fraternidad ritual", cuyo significado sería "creación de un hermano", celebradas por la Iglesia para unir a dos hombres y conocidas por la generalidad de los historiadores; hasta ahora habían sido interpretadas como la unión fraternal de dos hombres sin connotación sexual alguna, mientras que Boswell las interpreta como uniones del mismo sexo. No obstante, no ha dejado de ser criticado por otros historiadores, acusado de traducir los textos antiguos de forma tendenciosa -a este respecto, véase ERIBON (2000), p. 197.
} 
homosexualidad y, con ella, en la inmoralidad en general, la causa de la decadencia de Roma y finalmente la caída del Imperio Romano. Por el contrario, observando la literatura de la época descubrimos que esas afirmaciones no son ciertas ${ }^{12}$.

Un dato interesante al respecto es la discriminación existente ya en la época entre mujeres y varones, dándose a la homosexualidad femenina un trato de indiferencia, por lo que apenas se han conservado textos referidos a este tipo de relaciones. Es fácil comprenderlo si advertimos que prácticamente todos los escritores romanos eran varones y que si alguno tenía en cuenta este tipo de relaciones sexuales de la mujer, se inclinaría por considerarlas una forma de adulterio por parte de la mujer casada. Esta discriminación puede apreciarse también en la celebración de matrimonios homosexuales, de los que no se conoce la celebración de ninguno entre mujeres, debido a la indiferencia con que se trataba el lesbianismo ${ }^{13}$.

Otro dato significativo que muestra la igualdad de trato otorgada a las relaciones heterosexuales $\mathrm{u}$ homosexuales, fue la aplicación de igual condena ante violaciones de niños, independientemente de su carácter -heterosexual u homosexual. Se castigaba igualmente la violación a niños que a niñas, dado que la homosexualidad y la heterosexualidad eran equivalentes. Debía respetarse la minoría de edad, ya que su recato era considerado en alta estima sin que fuera castigado especialmente en el caso de violaciones homosexuales -destaca así el esfuerzo que mantuvieron siempre los romanos, a diferencia de los griegos, por proteger de los abusos sexuales a los menores de edad nacidos libres, tanto niños como niñas.

Puede considerarse al Imperio Romano, por todo lo expuesto, como pionero en Occidente en tolerancia social hacia los homosexuales. Fueron los primeros en Occidente en tratar sin hacer distinción ni en su religión ni en su derecho entre el erotismo y el amor homosexual y el heterosexual, permitiendo además la bisexualidad a los varones adultos - a pesar de la discriminación de género que esto supone. Y también, fueron los primeros en mostrar un tipo de relaciones homosexuales basadas en uniones fieles, profundas, que yendo más allá del sexo, se alejan de la promiscuidad mostrada en otras culturas, para culminar en una forma de vida.

Como hemos comprobado, en la Antigüedad encontramos culturas muy tolerantes, donde públicamente se acepta e incluso se admira el amor homosexual. Así, además de las Antiguas Grecia y Roma, encontramos el caso de la Antigua China,

\footnotetext{
${ }^{12}$ Boswell (1998); pp. 105, 106, 94.

${ }^{13}$ Boswell (1998), p. 107. Este autor, tras denunciar la indiferencia con que se trataba el lesbianismo en la Antigua Roma, ofrece algún texto en que se muestra el amor lésbico, como el de Luciano o Yámblico, quien narra el amor entre Berenice -hija del rey de Egipto- y Mesopotamia. Para ello cita, entre otras, obras clásicas.
} 
en cuya literatura popular destaca el amor homosexual de un gran emperador ${ }^{14}$; $\sin$ olvidar la literatura islámica que representaba las relaciones homosexuales como una alegoría de la relación espiritual entre Dios y el hombre ${ }^{15}$. Nada que ver estas culturas con la cultura judeo-cristiana, cultura medieval, impregnada de tabúes sociales y morales y prejuicios.

Tras la caída del Imperio Romano, penetra la ideología cristiana hasta llegar a gobernar política, cultural y socialmente en la Edad Media, produciéndose un cambio radical en la concepción sobre la homosexualidad. Hasta esta época la homosexualidad y, con ella, las relaciones homosexuales, se han considerado por lo general, normales, dentro de los parámetros de la cotidianidad, como una actividad biológica más del hombre dentro de su actividad o desarrollo sexual, salvando las diferencias culturales entre las distintas civilizaciones. Con la penetración del cristianismo, la doctrina católica y su estricta moral romperán los modelos establecidos hasta ahora para sentar sus propios pilares, instaurando sus propias normas sobre lo moralmente correcto o incorrecto, convirtiendo en pecado muchas conductas hasta ahora desapercibidas. A partir de este momento, las relaciones homosexuales dejarán de estar en el anonimato, como conductas normales del individuo, para ocupar "el punto de mira" de la Iglesia, la sociedad, los poderes públicos, los políticos e incluso de la medicina. A partir de esta época se producirá una larga evolución del concepto de homosexualidad. En un primer momento, la Iglesia la condenó como pecado, pasando inmediatamente a tipificarse como delito, siendo perseguido y sancionado, y finalmente, tras su destipificación penal, se catalogó como enfermedad. Recientemente, también se descubrió el error de catalogarlo como enfermedad, pero la Iglesia mantiene su tacha como pecado. Quienes han mantenido relaciones con su mismo sexo desde la llegada de la ideología cristiana han sido tachados, pues, de pecadores, delincuentes o enfermos, según la legislación de la época en que se les haya descubierto. Para entender el alcance de la influencia del cristianismo haremos un breve recorrido.

En este período histórico triunfa la condena eclesiástica de la homosexualidad, que llegará a convertirse en persecución y condena penal. Esto tiene su origen en la función meramente reproductora que la Iglesia Católica atribuye al sexo. En plena Edad Media hay una confusión entre la Iglesia y las instancias del poder político, identificándose el binomio Iglesia-Estado y, como consecuencia,

\footnotetext{
${ }^{14}$ Soriano (2005), p. 65.

${ }^{15}$ ARJONA (1990), p. 51. Este autor, en su obra, refleja la existencia de la homosexualidad concebida como práctica sexual permitida en la España musulmana, tal y como afirma literalmente que "la homosexualidad existió siempre en la España musulmana; al principio con un carácter clandestino, pero poco a poco con la relajación de costumbres llegó a ser en el periodo de los Taifas una cosa pública de la que nadie se recataba en pregonar pese a ser un tema rigurosamente condenado por el Islam".
} 
confundiéndose entre pecado y delito, repercutiendo sobre el homosexual -"pecador" - en su criminalización, quien debía ser perseguido y castigado por faltar a la Ley de Dios. Es tal la complicidad entre Estado e Iglesia que existía una doble jurisdicción: los tribunales estatales y el Tribunal de la Inquisición, encargados de aplicar sus respectivas leyes, llegando a confundirse incluso en muchos temas en los que ambos tenían jurisdicción. Tal es el caso de la homosexualidad. Ésta estaba penalizada por ambas jurisdicciones con gran severidad, llegando a ser más dura la eclesiástica.

Tendremos oportunidad de estudiar el comportamiento de la Iglesia y de su Tribunal Inquisidor más adelante, para comprender dónde se encuentra la raíz de la homofobia que se ha manifestado a lo largo de la historia contra la homosexualidad en nuestra sociedad, de tradición judeo-cristiana. Ahora es el momento de realizar un breve repaso histórico del panorama legal medieval español en relación a la homosexualidad.

Con la llegada de la represión del Antiguo Régimen y junto a la entrada en vigor del Liber Iudiciorum (S. XII) se promulgaron leyes contra las relaciones homosexuales -ley "de los hombres que yacen con otros hombres" o ley "de los sodomitas"-que contemplaban duras penas para tales delitos ${ }^{16}$. La primera, preveía el castigo de castración a los sodomitas -homosexuales- y su entrega a los obispos para su encarcelamiento, además de la disolución de su vínculo matrimonial cuando eran casados. La segunda de estas leyes, preveía la castración y la excomulgación. Sin embargo, ambas leyes hacían distinción entre eclesiásticos y legos, siendo más duros los castigos para estos últimos.

Tras la invasión de los árabes a la Península, se dividió territorialmente la actitud frente a las relaciones homosexuales. La cultura árabe trajo consigo la tolerancia frente a este tipo de relaciones en sus territorios, chocando frontalmente con la prohibición absoluta a la que estaban sometidas en los territorios cristianos. Efectivamente, el Corán condena la homosexualidad, aunque de forma moderada, por ser un tipo de relaciones sexuales que no da origen a la procreación. Sin embargo, la sociedad islámica ignoraba estas prohibiciones, practicándola con normalidad y convirtiéndose aquéllas en meros formalismos. Como explica G. Valdés, en los pueblos árabes, el único valorado era el varón, siendo considerada la mujer como una carga improductiva, de tal forma que incluso en algunos grupos tribales muchos jóvenes se iniciaban a la vida adulta a través de su relación sexual con los patriarcas ${ }^{17}$-aunque eran consideradas faltas graves la fornicación y la pederastia, si no estaban legalizadas por matrimonio o por ser relaciones entre señor y escla-

16 Boswell (1998), p. 302; Brundage (2000), pp. 215, 374.

${ }^{17}$ García (1981), p. 35. 
vo. No es de extrañar la tolerancia de los pueblos árabes hacia la homosexualidad frente a la represión sufrida en los territorios más occidentales. La clave radica en la diferencia de culturización entre Oriente y Occidente en aquélla época. Los pueblos orientales eran los más cultos, con civilizaciones más avanzadas en todos los sentidos y, por ello, los más tolerantes religiosa y sexualmente; sin embargo, los pueblos occidentales, mucho más atrasados y menos cultos, eran también los más obcecados y menos tolerantes.

En los territorios cristianos consolidados en la Reconquista se continuó aplicando el Liber Iudiciórum -siglo XII. En el siglo XIII, con Alfonso X, en su labor de unificación legislativa del Reino de Castilla, aparecen dos nuevos textos legales en los que se continúa castigando la homosexualidad -el Fuero Real y las Partidas-, aún más crueles que antes, condenándose en ambos el delito de realizar actos homosexuales con la pena de muerte, por primera vez en Europa, y calificándose dichos actos como contra natura. Otro punto importante de Las Partidas es el hecho de que en ellas se recogiese también por primera vez la homosexualidad femenina advirtiéndose, en principio, un tono de igualdad entre la homosexualidad masculina y el lesbianismo, puesto que éste era castigado con la hoguera. Sin embargo, terminaba explicando que este pecado no era tan grave como la sodomía masculina ya que "la mujer no es apta para obrar como principio activo $^{18}$ ". De este modo, se confirmaba una vez más el pensamiento de la época, según el cual el papel secundario de la mujer traía consigo que hasta su pecado era de menor relevancia.

Dos siglos más tarde, los Reyes Católicos dictaron una Pragmática de 1497, llamada "Como ha de ser castigado el pecado nefando contra naturaleza", en la que califica el delito de homosexualidad como herejía y crimen de Laesae Magestatis, y aumentan las penas que hasta ahora se venían dando a tal delito. En esta ley se castigaba al homosexual con la hoguera y la confiscación de todos sus bienes. Esta misma ley mantuvo su vigor durante el reinado de Felipe II. El único problema que planteaba era el de prueba, que por su insuficiencia hacía escapar a muchos culpables de la hoguera. Así pues, fue este monarca-Felipe II- quien eliminó el problema de la prueba a través de ciertas medidas, con su Pragmática de 1598 denominada "De la forma como se ha tener probado el pecado nefando contra naturam". Se establecía con ello que cualquiera podía denunciar a un sodomita ante el juez y morirían tanto quien cometió el pecado como quien lo consintió, salvo los menores de 14 años; esta legislación es la que finalmente recogió la Novísima Recopilación de 1805, acerca de la Homosexualidad, y son las penas que tuvieron vigor hasta la llegada del Código Penal de 1822. Tras un brevísimo período de

${ }^{18}$ Duby (1990), p. 102. 
vigencia de éste, volvió a regir de nuevo la Novísima Recopilación hasta 1848, fecha en la que entró en vigor el nuevo Código Penal.

En los siglos XVI y XVII, el delito más perseguido fue el de sodomía. Esto se debió a que junto a su calificación de delito, se le unía la de pecado y, por ello, era el más odiado por la sociedad en general. Tal fue la consideración de este delito y de su persecución que se le llegó a denominar vulgarmente como "el pecado"19.

Como hemos indicado antes, durante todo el período de la Edad Media, las relaciones homosexuales fueron perseguidas doblemente: por los tribunales estatales y por la Inquisición Española. Es decir, paralelamente a los grandes perseguidores de la homosexualidad -los tribunales estatales-, existía otra persecución llevada a cabo por el tribunal de la Inquisición. No obstante, ésta persiguió a los homosexuales sólo cuando se les relacionó con casos de herejía. No olvidemos que su principal objetivo fueron los herejes - principalmente judíos y moriscos- y, por ello, fue más cautelosa que los tribunales estatales en la aplicación de la pena de muerte para el delito de sodomía. El castigo previsto para los sodomitas era la hoguera -para mayores de 25 años- y de azotes y galeras para los menores; sin embargo, como ya se ha dicho, para su aplicación debían relacionarse con casos de herejía. En las leyes penales de los distintos reinos cristianos equiparaban al sodomita con el ladrón y el hereje, pero tratándole de modo más vejatorio al calificarlo como de crimen contra naturaleza.

La caída del Antiguo Régimen supuso la despenalización de la homosexualidad. Fueron las leyes napoleónicas las que pusieron fin a la pena de muerte para los sodomitas mientras la sociedad se hacía más laica. El Código Penal de 1822, influenciado por el Código Penal francés de 1810, no tipifica el delito de sodomía. Se suprime además definitivamente el Tribunal de la Inquisición. Así las cosas, las relaciones homosexuales dejaron de estar perseguidas tanto por los tribunales estatales como por el ya desaparecido Tribunal Inquisidor. No obstante seguía condenándose a muchos homosexuales por delito de escándalo público o faltas contra la moral y las buenas costumbres, a causa de la ideología dominante en la sociedad, reflejada en una práctica judicial en la que se seguían plasmando los prejuicios históricos. Además, el delito de sodomía seguía tipificado en los Códigos Militares. El siglo XIX fue, por tanto, un período de grandes transformaciones sociales, fue la época de la "paulatina secularización de la sociedad"20. De este modo, se separan la ley del credo, esto es, el delito del pecado -concebidos hasta ahora como una sola cosa.

${ }^{19}$ Tomás y Valiente (1969), p. 225.

${ }^{20}$ Boswell (1998), p. 25. 
Poco a poco, la homosexualidad deja de considerarse esa conducta abominable y, a pesar de continuar considerándose pecado, ya no lo será como delito, ya ha dejado de tipificarse en las leyes penales, al menos directamente como tal. Ahora bien, en esa nueva época se califica de vicio, enfermedad, desviación de la naturaleza humana, llegando a caracterizarla como enfermedad mental. Fue, por lo tanto, la psiquiatría la ciencia a la que se encargó el tratamiento y rehabilitación de los homosexuales como enfermos mentales ${ }^{21}$.

Ya en el siglo XX, se vuelve a tipificar la homosexualidad como delito en el Código Penal de 1928 -durante la dictadura del General Primo de Rivera-, el cual recoge dos tipos delictivos: el delito de abusos deshonestos y el delito de escándalo público. En realidad, no es que en estos supuestos la comisión del delito dependiese de que la conducta delictiva fuese homosexual, pero en caso de serlo, las penas se agravaban considerablemente respecto a las mismas conductas heterosexuales; esto es, la homosexualidad estaba tipificada como agravante, constituyendo las conductas homosexuales causa agravante en el Código Penal. No obstante esta situación no permaneció durante mucho tiempo, ya que el Código Penal de 1932 derogó tales preceptos haciendo desaparecer definitivamente la tipificación penal de la homosexualidad. De todos modos, esto no pudo evitar que se siguiera asociando a las viejas figuras del escándalo público y del delito deshonesto, ya que para su disociación aún faltarán algunos años.

Ésta fue una época de grandes acontecimientos históricos en el resto de Europa, provocados por la ideología nacionalsocialista y el resto de movimientos fascistas, que no fue indiferente respecto a las relaciones homosexuales, sino que introdujo nuevas técnicas represivas contra la homosexualidad. En la Unión Soviética, con la llegada de Stalin al poder, dejó de admitirse libremente la homosexualidad y empezó a considerarse un peligro social que había que perseguir y castigar ${ }^{22}$. Las persecuciones y detenciones a homosexuales se convirtieron en algo tan frecuente en la Unión Soviética que, sirvieron de tapadera perfecta para eliminar a políticos y contrarrevolucionarios que no compartían las ideas stalinistas, acusados de homosexualidad. El Nazismo, movimiento ideológico de fundamento racista, tenía entre sus postulados el objetivo de "depurar la raza germánica", para lo cual mataron a millones de personas pertenecientes a razas consideradas inferiores (judíos), por considerarlas defectuosas, entre ellas, muchos homosexuales. Para la mentalidad

\footnotetext{
${ }^{21}$ GARCÍA (1981), p. 106. Este autor señala que uno de los médicos -especialistas en la materia- defensores del tratamiento de los homosexuales como enfermos fue el alemán Friedrich, quien condenó la homosexualidad asimilándola a un "estado vicioso y enfermizo".

${ }^{22}$ García (1981), p. 107. Este autor, para sostener su tesis, cita a Máximo Gorka, quien afirmó que: "en los paises fascistas, la homosexualidad, azote de la juventud, florece sin el menor castigo; en el pais donde el proletariado ha alcanzado el poder social, la homosexualidad ha sido declarada un delito social y es severamente castigada".
} 
nazi, la sexualidad -como toda manifestación del individuo- es algo al servicio del Estado, quien puede dominar absolutamente sobre toda la población, y por ello los individuos no pueden disponer libremente su orientación sexual. Por esta razón, se tipificaron penalmente todo tipo de relaciones homosexuales, siendo condenadas incluso con la pena de muerte.

En España, tras la Guerra Civil española, la dictadura franquista trajo una nueva época de represión de la homosexualidad. En una primera etapa se les consideró peligrosos sociales y después se les asoció al delito del escándalo público. La homosexualidad, efectivamente, no estaba tipificada penalmente, pero sí en la Ley de Vagos y Maleantes, reformada en 1954 en el sentido de crear medidas de seguridad -de privación de libertad y vigilancia- contra los homosexuales por considerarlos peligrosos contra la sociedad. Además, en otros ámbitos como el de la docencia, se consideraba un defecto físico o enfermedad que impedía para el ingreso como docente de Enseñanza Primaria ${ }^{23}$. Por otra parte, se encontraba aún penado en el ámbito militar, tipificado en el Código de Justicia Militar de 1945 con penas de prisión y con la separación del servicio.

En 1970, la Ley de Vagos y Maleantes fue sustituida por la Ley de Peligrosidad y Rehabilitación Social. Se diferencia de la anterior ley en que si bien antes eran inculpados los homosexuales, ahora sólo lo serán quienes ejerzan actos de homosexualidad, exigiéndose además una habitualidad o frecuencia en sus actos -no basta un solo hecho aislado para considerar peligroso al individuo. No están por tanto tipificadas penalmente las conductas homosexuales en cuanto tales, sino que a través de estas leyes se castiga penalmente a los homosexuales que las practicaban con regularidad con condenas privativas de libertad y vigilancias continuas, por considerarlos sujetos socialmente peligrosos y necesitados de medidas de seguridad necesarias para rehabilitarlos ${ }^{24}$.

Por otra parte, existía una figura en el Código Penal -la del escándalo público-, que los tribunales utilizaron para condenar penalmente las prácticas homosexuales. Facilita tal hecho el carácter de este tipo penal. Efectivamente, no contempla explícitamente las prácticas homosexuales, si bien es el tipo idóneo para ser aplicado por los tribunales para reprimir tales prácticas, de acuerdo con la ideología oficial, debido a su carácter de norma en blanco. Fue el Tribunal Supremo el primero en relacionar la homosexualidad con el escándalo público, aplicando pues el tipo penal de éste a las prácticas homosexuales. De este modo, ya podía vaticinarse la

\footnotetext{
${ }^{23}$ Orden del Ministerio de Educación y Ciencia (Gobierno de España), de 1971.

${ }^{24}$ ARNaLTe (2003), p. 21. Este autor explica que, dada la presunción de que el homosexual era un ser desviado, se creó el Departamento de Homosexuales, puesto en marcha desde la Central de Observación de Presos, con la finalidad de observar, diagnosticar el tipo de desviación y curar a los homosexuales internos en la cárcel.
} 
dureza del Tribunal Supremo respecto a la homosexualidad y así lo manifestó en continuos pronunciamientos impregnados de crueldad. La homosexualidad ya se presumía de escándalo público porque per se atentaba contra la "moral sexual pública"25.

En primer lugar, se les exigía la obligación de "absoluta clandestinidad"26, para proteger al resto de las personas de la grave ofensa que pudiera suponer conocer de tal horror. Por lo tanto, se les imponía ese deber de "secreto de las nefandas relaciones" ${ }^{27}$. Con todo ello, llegamos a una única conclusión: no se protege el escándalo público ya que, en principio, para que se dé éste es necesaria una cierta publicidad, que lo sepa un cierto número de personas, que tenga una cierta divulgación y, por supuesto, que sean los protagonistas quienes provoquen con su actitud que su conducta sea así. Sin embargo, en el caso de las conductas homosexuales se rompían todas las reglas: el escándalo público se caracterizaba por el hecho en sí, sin importar la publicidad que tuviera. Tal y como el mismo Tribunal Supremo expresó en uno de sus pronunciamientos: "no radica en la mayor o menor divulgación del hecho (...), sino en su propia naturaleza escandalosand. Incluso se protegen persecuciones e invasiones en el derecho a la intimidad para descubrir "in fraganti" 29 a una pareja de homosexuales para denunciarlos.

En cuanto al lesbianismo, éste tampoco era admitido por los tribunales, pero pasó casi inadvertido. Esta diferencia de trato tiene su origen en la discriminación sexual o discriminación de género. Desde el principio de los tiempos, la mujer ha venido arrastrando dos enormes lastres: su rol sexual pasivo y su exclusiva función sexual procreadora o para dar placer al hombre. Ha costado muchos siglos reconocer que la mujer también siente placer y tiene derecho a su realización sexual. Por esa concepción del rol sexual de la mujer es por lo que se tenía en tan poca consideración la homosexualidad femenina; en definitiva, no eran tenidas en cuenta sin el elemento activo -el hombre. Por ello, el lesbianismo se vio mal, impúdico, inmoral, pero se pasó más por alto porque se consideró algo propio de mujeres y, por supuesto, desconectado de la sexualidad -todo lo contrario que entre hombres. La homosexualidad femenina o lesbianismo, siendo una práctica sexual tan antigua como la homosexualidad masculina, ha sido prácticamente ignorada básicamente por un motivo: la falta de reconocimiento de la sexualidad

\footnotetext{
${ }^{25}$ STS de 5 de noviembre de 1974.

${ }^{26}$ STS de 20 de diciembre de 1966.

${ }^{27}$ STS de 20 de diciembre de 1966.

${ }^{28}$ STS de 30 de noviembre de 1953.

${ }^{29}$ STS de 27 de octubre de 1965.
} 
propia a las mujeres. Afortunadamente, fruto de dicha ignorancia, la mujer resultó beneficiada en esta ocasión por tal diferencia de trato ${ }^{30}$.

\section{LA INTOLERANCIA COMO CAUSA DE LA REPRESIÓN DE LA HOMOSEXUALIDAD}

Tras este recorrido histórico, es fácil descubrir que hay una idea persistente en todo él, la verdadera causa de intolerancia a la homosexualidad, cual es, la intolerancia social, adornada frecuentemente por otro tipo de causas, sobre todo la intolerancia religiosa. Hay autores como Boswell, sin embargo, que argumentan que esa no es la auténtica causa.

Este autor, realiza un estudio exhaustivo del tema a través del cual intenta demostrar que la idea de que la creencia religiosa ha sido la causa de la intolerancia a la homosexualidad es falsa. A través de arduas investigaciones históricas y sociológicas, y con ejemplos literarios, trató de fundamentar su teoría de que la creencia religiosa ha sido a lo largo de la historia la tapadera perfecta para justificar la condena contra algo hacia lo que la generalidad popular sentía "animadversión personal o prejuicio" 31 -la homosexualidad. Así pues, su teoría vendría a exculpar a la religión de la condena a la homosexualidad, argumentando que el único artífice de dicha condena ha sido la intolerancia popular.

Sin embargo, este análisis parece obviar actuaciones más que discutibles por parte de la Iglesia. A este respecto, pasa por alto la existencia de conductas igualmente condenadas en los libros en los que injustamente se condena la homosexualidad, tales como la hostilidad, la hipocresía o la codicia sin que, sin embargo, jamás fueran considerados pecadores contra natura los hipócritas ni sufrieran las graves penas a las que fueron sometidos los homosexuales. Es más, incluso puede afirmarse que los Estados cristianos medievales hacían una selección del Nuevo Testamento, usando sólo las restricciones bíblicas que les convenían. No olvidemos la dura condena que el Nuevo Testamento hacía de la prostitución y sin embargo en muchos Estados medievales se autorizaba dicha práctica, mientras se quemaba en la hoguera a los homosexuales, apenas mencionados en dicho texto bíblico. Así pues, la teoría de este autor es más que discutible, ya que existen fundamentos suficientes como para sostener que en realidad la religión sí ha sido un factor importante de discriminación hacia los homosexuales.

Los homosexuales constituían una minoría oprimida y rechazada y sin embargo nunca se han unido como las otras minorías existentes en la época -musulmanes y judíos-, sino que sobrevivían dispersos entre la población. Quizá el fundamento

${ }^{30}$ Arnalte (2003), p. 219.

${ }^{31}$ Boswell (1998), p. 29. 
de su persecución y condena radica en la idea de que constituían un peligro. Por regla general, los prejuicios sociales más fuertes nacen como respuesta al peligro que en los rechazados ven los que los perjudican. Así ocurría también con las brujas, por poner algún ejemplo, y a día de hoy resulta ridículo el temor que pudiera atribuírseles, considerándose más bien un pretexto imaginario para condenar a ciertos grupos. Sin embargo, esta animadversión hacia los homosexuales, aún hoy está bastante extendida. Es difícil encontrar una explicación exacta de la naturaleza de esta creencia de considerar a los homosexuales una "amenaza" que, por otra parte, no ha sido siempre la misma, ya que ha ido evolucionando a lo largo de la historia y nunca ha estado falta de contradicciones e incoherencias.

En primer lugar, está la idea de que las sociedades que admiten y toleran abiertamente la homosexualidad lo hacen en su propio detrimento, fundada en la tesis de que cuando no se ponen trabas a este tipo de prácticas, se manifestarían como tales un número de personas muy superior al que lo hace en sociedades donde tienen dificultades para hacerlo por falta de tolerancia. Sin embargo, las teorías científicas han demostrado que la tolerancia social no es un parámetro que determine la incidencia de la homosexualidad, constituyendo ésta en todo caso una minoría. Esta tesis, sustentada sobre la idea de que en las sociedades tolerantes hay una gran inclinación por la homosexualidad, encuentra en ese punto la naturaleza de la "amenaza" que representa la homosexualidad. La amenaza radica en el hecho de que al convertirse en sociedades donde la mayoría de su población opta por la homosexualidad, corren el peligro de extinguirse. Autores como Boswell combaten este razonamiento argumentando que no existen datos que sustenten la incompatibilidad entre el comportamiento físico homosexual y heterosexual. Esto es, un individuo puede ser homosexual y tener deseo sexual de orientación homosexual - "contacto erótico" - y, a la vez, tener contacto sexual puramente físico para tener descendencia. En este punto, ciertamente, son muchos los personajes famosos que, a lo largo de la historia, han sido conocidos por su homosexualidad -Óscar Wilde, Sócrates- ${ }^{32}$ y de los que, en cambio, prácticamente se ha ignorado su condición de esposos o padres, por el mito de negar la reproductividad a los homosexuales. Por otra parte, frente a lo que afirma la mencionada tesis, no está comprobado que en las sociedades tolerantes se opte mayoritariamente por la homosexualidad -como se mantiene en ella-, sino por la heterosexualidad, como opción claramente predominante en todas las culturas y sociedades, aun con el florecimiento de la homosexualidad en sociedades más abiertas y tolerantes.

Una segunda tesis surgida para justificar la amenaza que constituía la homosexualidad era su consideración de "antinatural". Puesto que los homosexuales tenían

32 ERIBOn (2001), pp. 197-308. 
una orientación diferente a la mayoría no se les toleraba, por tener preferencias antinaturales. Muchas veces, desde el principio de los tiempos, se ha hablado de antinatural, contra naturaleza, al referirse a la homosexualidad, pero ¿qué significan realmente los términos "naturaleza" o "antinatural"? Una primera idea de lo antinatural, radica en la falta de reproducción, según la cual se ha intentado argumentar que el comportamiento sexual en sí mismo no reproductivo es antinatural. No parece justificar, sin embargo, la intolerancia hacia este tipo de relaciones en ninguna de las épocas en que así ha ocurrido. Basta para ello recordar que en todas las sociedades, desde las más antiguas hasta las más modernas, se han permitido como naturales comportamientos sexuales -según la época- que tampoco son en sí mismos reproductivos.

Otro argumento histórico para apoyar la antinaturalidad del comportamiento homosexual, ha sido la idea de que la homosexualidad sólo se da entre la especie humana, pero no entre ningún otro animal. No hay mucho que explicar para demostrar el error de esta teoría. Está comprobado que existen comportamientos homosexuales prácticamente entre todas las especies animales y claro es que nadie dirá que estos comportamientos son antinaturales, sino parte de la naturaleza.

Por último, existe una idea para explicar la antinaturalidad, que se aparta completamente de la dicotomía "natural-antinatural", para centrarse en la llamada naturaleza ideal. Esta teoría parte de una naturaleza perfecta, impoluta y buena, por lo que todo lo vicioso, perverso o malo se considera "antinatural", ya que la naturaleza no puede en ningún caso generar el mal. Así las cosas, una conducta viciosa o perversa, repudiada por la sociedad, como es la homosexualidad, no puede haberla creado o generado la naturaleza, porque es una conducta mala. Por ello se considera antinatural, independiente de que la practiquen los animales o los seres humanos. Sin embargo, esta idea preconcebida de que la naturaleza es perfecta, ideal, no es sostenible, como tampoco lo es la catalogación de que la homosexualidad es perversa y mala. Estas nociones no parecen convincentes ni científica ni moralmente; más bien son el resultado de la fusión entre prejuicios históricos e ideas erróneas sobre la naturaleza.

La historia del prejuicio contra la homosexualidad no es pues, sino la historia de la tolerancia social. Tolerancia social, claro es, que mejor podríamos denominar "intolerancia social", porque son muy pocas las épocas en las que se les ha respetado, en comparación con la cantidad de siglos y en la multitud de sociedades en las que se les ha reprimido, fruto de la intolerancia. Como hemos observado, paseando por cada una de las épocas, sociedades y culturas que nos han precedido, desde los pueblos prehistóricos hasta la sociedad democrática española, el tratamiento que se ha dado siempre a la homosexualidad no ha dependido tanto de leyes u otras cuestiones, sino de tolerancia y, en función 
de ésta, ha girado todo lo demás -así, se ha catalogado como pecado, delito o enfermedad, respectivamente.

Si observamos detenidamente la historia del prejuicio contra los homosexuales, como minoría, es fácil descubrir que no son un grupo aislado en su tratamiento hostil o tolerado, según la sociedad en la que se realice el estudio. Junto a los homosexuales, aparecen otros grupos minoritarios -minorías religiosas- que, a lo largo de la historia, han sufrido el mismo tratamiento que ellos, fruto de la intolerancia/tolerancia social. De este modo, la mayoría de las sociedades que admitían la diversidad religiosa, admitían también la variedad de orientación sexual. En la misma línea, las sociedades que oprimieron a las minorías religiosas oprimían a los homosexuales -recordemos que los mismos grupos que oprimían y exterminaban a los judíos en campos de concentración, trataron de hacer lo mismo con los homosexuales.

Debido a la intolerancia social que han sufrido, los homosexuales casi siempre han permanecido ocultos, en el anonimato. Tan solo en las culturas más tolerantes se han dado a conocer, formando una especie de subculturas, algo así como grupos para hacerse visibles. La intolerancia social, causa de este ocultismo, obstaculiza en gran medida la investigación histórica de la homosexualidad.

Otra dificultad adicional para su conocimiento es que versa sobre cuestiones íntimas del individuo: relaciones sexuales, emociones y sentimientos y, por ello, es extraño encontrar documentos históricos que lo reflejen. Los principales documentos para estudiar el tema son literarios. Sabido es que la literatura es el vivo reflejo de la sociedad en una determinada época ${ }^{33}$, de la vida de sus gentes, de sus experiencias, de sus sentimientos, de su historia, de sus relaciones personales. Por tanto, son las fuentes literarias las más válidas y ricas para estudiar la historia de la homosexualidad, la permisión de sus tipos de relaciones, sus uniones, si bien dichas fuentes no dejan de plantear ciertas incógnitas ${ }^{34}$.

\footnotetext{
${ }^{33}$ Aquí, es importante apuntar que, existe un problema en el estudio de las fuentes literarias. Si cada cultura tuvo conocimiento de los antecedentes literarios de una cultura anterior, no se sabe si lo que escribe como propio es de nueva creación, representando sus sentimientos, o imitación de lo anterior. No obstante, una cultura puede haber leído las obras de una cultura anterior pero evidentemente, la orientación sexual es una elección muy limitada: heterosexualidad, homosexualidad o bisexualidad, no existen más. En cada cultura escribirán expresando sus sentimientos, sus vivencias y si escriben literatura homosexual es porque así lo viven, no porque lo han leído antes, al igual que la literatura heterosexual tampoco será heterosexual por imitación a lecturas previas.

${ }^{34}$ SAUQUiLlo (1986); SASLOW (1989). Estos autores muestran a través de la literatura y el arte, respectivamente, la represión y persecución sufrida por los homosexuales, a causa de la intolerancia social. Especialmente, reflejan a través de la obra lorquiana el modo de vida, el sentir del homosexual en la España de la época, así como la persecución ejercida sobre ellos.
} 
Otra dificultad en el estudio de la intolerancia de la homosexualidad, es la antigüedad del prejuicio que se mantiene contra ella. Esta antigüedad ha dado como resultado la falsificación de los documentos históricos que la reflejaban. Si bien se conservan prácticamente inalterados los textos sobre el tema procedentes de las antiguas civilizaciones, se produce un cambio radical sobre él en la Europa Medieval, cuyo eje central gira en torno a la pérdida de información, la distorsión de textos y la censura. Tras conocer la persecución sufrida por los homosexuales en dicha época, no es de extrañar que emplearan tantos esfuerzos por ocultar al público la existencia de conductas homosexuales, alterando para ello los textos literarios. Es complicado el estudio de la intolerancia, el estudio de la homosexualidad, por las trabas que la propia historia ha puesto. Sin embargo, esas propias trabas son la prueba fehaciente de la existencia del tratamiento que se ha dado a los homosexuales por cada cultura. La verdadera razón de la intolerancia social sufrida por los homosexuales en esta época se debió a la imposición de las ideas religiosas y morales desde el gobierno. Se buscaba una única moral, una unidad religiosa total, con una ausencia de libertades -incluida la libertad de pensamiento-, que no permitía tener una propia moral. Esta es la raíz de la fuerte represión medieval hacia los homosexuales. Un gobierno poderoso, con medios de actuación, que quiere controlar cuestiones personales de cada individuo como es la propia religión o la moral, puede igualmente regular otras cuestiones más íntimas como la sexualidad. Además, dicho gobierno cuenta con una gran ventaja, los homosexuales siempre han constituido una minoría - dispersa-, por lo que no podrán hacer fuerza para oponerse. Tal era el control del gobierno sobre la creencia religiosa del pueblo que se instauró el lema "Vox populi vox Dei". Ésta era la fórmula más eficaz de obtener la obediencia absoluta del pueblo; cualquiera que no estuviera de acuerdo con la voz del pueblo, estaba contra Dios. Así era más fácil perseguir a todas las minorías -judíos, homosexuales. Constituían minorías todos los que se concebían como diferentes y, por ello, equivocados, y acababan siendo considerados "antinaturales" o "peligrosos".

Actualmente, no hay que probar la naturalidad de la homosexualidad ni su falta de peligrosidad. Ya son visibles y conviven "pacíficamente", en una sociedad democrática donde no se les condena por no ocultar ser lo que son. Sin embargo, el reconocimiento de su existencia no ha sido más que el primer paso del reconocimiento para todos de una serie de derechos, previstos por la Constitución, y que históricamente se les han negado o limitado por ser homosexuales y compartir su vida con alguien de su mismo sexo. Visto así, ¿podemos afirmar que se ha alcanzado la tolerancia? 


\section{SitUACIÓN PRESENTE: LAS ORGANIZACIONES INTERNACIONALES Y SU ACTITUD FRENTE A LA HOMOSEXUALIDAD}

\section{III.1. Organismos europeos y politica antidiscriminatoria}

La Declaración Universal de los Derechos del Hombre, aprobada por la Asamblea General de la ONU el 16 de diciembre de 1948, todavía no ha reconocido el derecho inalienable de toda persona a no ser discriminada por causa de su orientación sexual. Sin embargo, en Europa se aprecia una importante evolución. Si bien el Convenio de Derechos Fundamentales, de 1950, no incluía en su mandato de igualdad la prohibición de discriminación por orientación sexual, han sido Tratados de Derechos posteriores los que la han incluido de manera expresa. Estos, en su tratamiento de la igualdad, hacen prohibición expresa de la discriminación basada en la orientación sexual a idéntico nivel que el resto de causas tradicionalmente prohibidas. Así ocurre con la Constitución Europea -ratificada por España, aunque sin efectos por su falta de entrada en vigor. Como es sabido, el proyecto de Constitución Europea contenía una parte dedicada a derechos fundamentales, que no era sino una transcripción de la Carta de los Derechos Fundamentales de la Unión Europea de 2000, entre los que se encuentra el artículo II-81, dedicado a la prohibición de discriminación (reproducción del artículo 21 de la Carta).

Como es sabido, la mencionada Constitución Europea no llegó a ser aprobada, si bien pocos años después, el contenido de la Carta de Derechos fue incorporado al Tratado de Lisboa (aprobado en diciembre de 2007). La diferencia entre ambos textos -Carta de los Derechos Fundamentales de la Unión Europea y Tratado de Lisboa- es importante, ya que mientras el primero es una mera declaración de derechos, el segundo por tratarse de un Tratado internacional, tiene plenos efectos jurídicos, vinculantes para las partes firmantes. Por este motivo, el precepto que recoge la igualdad y el derecho a no ser discriminados, aunque mantiene la misma redacción en los dos textos, adquiere eficacia jurídica. Así pues, el Tratado de Lisboa reza: 1.- "se prohibe toda discriminación, y en particular la ejercida por razón de sexo, raza, color, orígenes étnicos o sociales, características genéticas, lengua, religión o convicciones, opiniones políticas o de cualquier otro tipo, pertenencia a una minoría nacional, patrimonio, nacimiento, discapacidad, edad u orientación sexual"; 2.- "se prohíbe toda discriminación por razón de nacionalidad en el ámbito de aplicación del Tratado Constitutivo de la Comunidad Europea y del Tratado de la Unión Europea $y$ sin perjuicio de las disposiciones particulares de dichos Tratados".

De esta manera, la "orientación sexual" constituye una de las causas expresamente prohibidas de discriminación, por lo que cualquier medida fundada en dicha causa, deberá superar un juicio estricto que justifique el trato diferenciado, argumentando así su constitucionalidad. 
A este respecto, es conveniente apuntar que el primero de los tratados europeos en considerar la prohibición de discriminación por orientación sexual con la finalidad de promover la igualdad en su sentido más amplio fue el Tratado de Ámsterdam ${ }^{35}$ y, a partir de este, ciertas Resoluciones del Parlamento Europeo -como se verá a continuación; otros textos normativos, en cambio, no la prevén expresamente aunque sí explicitan la igualdad de trato en general ${ }^{36}$ y su claro propósito de lucha contra la discriminación.

Por otra parte, como se ha apuntado, desde la década de los 80 se ha producido un gran avance en este sentido, tras la aprobación de tres Recomendaciones antidiscriminatorias de la homosexualidad: una del Consejo de Europa y dos del Parlamento Europeo, expuestas a continuación:

* Resolución del Consejo de Europa, de 1 de octubre de $1981^{37}$. Declara el derecho a la autodeterminación sexual de hombres y mujeres, "en edad legal de consentimiento prevista por las leyes del país donde viven, y capaces de consentimiento personal válido".

En la misma Resolución se recoge también una invitación a la Organización Mundial de la Salud (OMS) para que suprima la homosexualidad de su Clasificación Internacional de Enfermedades (CIE). Sin embargo, no se aprobó otra propuesta de Resolución solicitando y recomendando la modificación del artículo 14 de la Convención Europea de los Derechos del Hombre añadiendo la noción de tendencia sexual ${ }^{38}$.

La importancia de la Resolución de 1981 radica en haber sido el primer reconocimiento público por parte de un organismo internacional a ser homosexual y

\footnotetext{
${ }^{35}$ Artículo 13 del Tratado de Ámsterdam: "el Consejo, por unanimidad, a propuesta de la Comisión y previa consulta al Parlamento Europeo, podrá adoptar acciones adecuadas para luchar contra la discriminación por motivos de sexo, de origen racial o étnico, religión o convicciones, discapacidad, edad u orientación sexual". También es destacable por su contenido la Resolución del Parlamento Europeo de 1994, elaborada para la Igualdad de homosexuales y lesbianas..., con la deficiencia de que no tiene fuerza vinculante; en esencia "reitera su convicción de que todos los ciudadanos y ciudadanas tienen derecho a un trato idéntico, con independencia de su orientación sexual". Sobre esta Resolución, véase Capítulo I.

${ }^{36}$ Directiva 2000/78/CE, del Consejo de 27 de noviembre de 2000, relativa al establecimiento de un marco general para la igualdad de trato en el empleo y la ocupación. También podemos destacar la: Decisión del Consejo de 27 de noviembre de 2000, por la que se establece un programa de acción comunitario para luchar contra la discriminación (2000-2006).

${ }^{37}$ Recomendación Europea núm. 924.

${ }^{38} \mathrm{El}$ artículo 14 de la Convención Europea de los Derechos del Hombre establece el principio de igualdad y no discriminación de los derechos y libertades reconocidos en la Convención, prohibiendo distinción alguna "basada especialmente en el sexo, la raza, el color, la lengua, la religión, las opiniones políticas o de cualquier otro tipo, el origen nacional o social, la pertenencia a una minoría nacional, la fortuna, el nacimiento o cualquier otra situación".
} 
no sufrir discriminación por ello. Su valor práctico es muy reducido por tratarse de una Recomendación y carecer, por tanto, de carácter vinculante.

* Resolución del Parlamento Europeo, de 13 de marzo de 1984, sobre las discriminaciones sexuales en el lugar de trabajo. Advierte que "en la lucha contra las discriminaciones de cualquier tipo, no se puede ignorar o aceptar pasivamente las discriminaciones, de hecho o de derecho, contra los homosexuales". Sus efectos jurídicos son también limitados.

En la actualidad, son numerosos los países que han seguido las directrices de esta Resolución. Los pioneros en seguirlas fueron países como Dinamarca, desde 1989; Noruega, desde 1993, y Suecia, desde 1994, mediante la aprobación de leyes que equiparan jurídicamente las parejas homosexuales a las heterosexuales unidas por un vínculo matrimonial, salvo en el derecho a la adopción de niños. Holanda es también otro ejemplo a imitar, como tendremos ocasión de estudiar en el apartado de Derecho comparado.

En esta línea antidiscriminatoria también merece ser mencionado el avance experimentado en ámbitos que exceden las fronteras comunitarias. En Estados Unidos, cabe mencionar como ejemplo la ciudad de Nueva York, donde en 1993 se dictó una ordenanza por la que se ampliaron los derechos de las parejas homosexuales en determinadas materias de competencia municipal para igualarlos a los de las parejas heterosexuales, a la vez que quedaban igualadas en este aspecto las que lo fueran matrimonialmente y las que lo fueran solamente de hecho. Tras esta ordenanza, los neoyorquinos que se acrediten como "compañeros domésticos" gozarán de los mismos derechos de visita en hospitales y cárceles, así como en materia de acceso o herencia de un apartamento alquilado.

Sin embargo, la otra cara de la moneda la representaba Irlanda, que conservaba leyes aprobadas en el Parlamento Británico en 1861 y 1885, por las que las personas sorprendidas en actos de homosexualidad podían ser condenadas. Esta legislación ha sido derogada después de que un fallo del Tribunal Europeo de Derechos Humanos ${ }^{39}$ estimara que dichas leyes constituyen un atentado contra los derechos de la persona. El 24 de junio de 1993, el Parlamento irlandés aprobó una ley despenalizando las relaciones homosexuales entre los mayores de 17 años. Otro ejemplo reciente lo ha constituido la legislación austriaca aprobada en 1988, legislación que se ha mantenido en vigor hasta febrero de 2003, en la que se prohibían las organizaciones homosexuales, la publicidad sobre estos temas y la prostitución masculina, aunque no la femenina. Asimismo, la ley

${ }^{39}$ STEDH, de 26 de octubre de 1988, "asunto NORRIs". 
situaba la mayoría de edad en los 18 años para las relaciones homosexuales ${ }^{40} \mathrm{y}$ en los 14 para las relaciones heterosexuales -las relaciones homosexuales entre menores de 18 años, son tipificadas en el antiguo Código Penal Austríaco, artículo 209, hasta 2003.

* Resolución del Parlamento Europeo, de 8 de febrero de 1994, sobre la igualdad de derechos de los homosexuales y de las lesbianas en la Comunidad Europea. Las propuestas aprobadas en esta Resolución son verdaderamente avanzadas e innovadoras en materia de equiparación de la pareja de gays y lesbianas con el matrimonio heterosexual. Algunos ejemplos son el reconocimiento del acceso al matrimonio o a una situación jurídica equivalente, permitiéndole la inscripción de la convivencia y garantizándole plenamente los mismos derechos y beneficios de los que gozan las uniones matrimoniales, entre los que incluye el derecho de los gays y lesbianas a ser padres, a adoptar y a criar niños. En esencia, lo que literalmente reivindica esta Recomendación es lo siguiente: “... la recomendación debería, como minimo poner fin: a la prohibición de contraer matrimonio o de acceder a regímenes jurídicos equivalentes a las parejas de lesbianas o de homosexuales; la recomendación debería garantizar los plenos derechos y beneficios del matrimonio, permitiendo la inscripción de la convivencia. También debería como minimo tratar de poner fin a toda restricción de los derechos de las lesbianas y de los homosexuales a ser padres, a adoptar o a criar niños ${ }^{211}$. En esencia, la idea central de esta Resolución es reiterar que: "todos los ciudadanos y ciudadanas tienen derecho a un trato idéntico, con independencia de su orientación sexual". Para alcanzar tal objetivo, pide a los Estados miembros que "pongan fin al trato desigual de las personas de orientación homosexual en las disposiciones jurídicas y administrativas". Finalmente, pide a la Comisión Europea que "presente una propuesta de recomendación sobre la igualdad de derechos de las lesbianas y los homosexuales", en la que debería "como minimo", poner fin a la prohibición de contraer matrimonio y a la restricción del derecho a ser padres de los homosexuales. Sin embargo, una vez más se plantea como "Recomendación", es decir, sin carácter obligatorio en su cumplimiento por parte de los países comunitarios, y no como Directiva.

Sin embargo, tras la anterior Resolución, caracterizada por la gran repercusión popular que alcanzó, el Parlamento Europeo aprobó una nueva Resolución, de 14 de diciembre de 1994, en la que manifestó un cambio de actitud, consecuencia del nuevo periodo legislativo del Parlamento. No obstante, no supuso modificación alguna para la anterior Resolución, de 8 de febrero, si bien es cierto que tampoco

${ }^{40}$ Relaciones homosexuales entre menores de 18 años, tipificadas en antiguo Código Penal Austríaco, artículo 209, hasta 2003.

${ }^{41}$ Resolución del Parlamento Europeo A3-0028/94. 
se logró la pretendida inclusión como familia de las parejas de homosexuales, puesto que se suprimió el párrafo que así lo preveía.

De cualquier modo, el tema de las uniones homosexuales y su equiparación a las parejas heterosexuales, la posibilidad del reconocimiento al derecho al matrimonio para ellos, la elaboración de leyes de uniones homosexuales que les reconozcan sus derechos como pareja, y, más aún, la posibilidad de la adopción de hijos, no son temas pacíficos. No están resueltos aún a nivel estatal y, desde las instituciones y organismos europeos, aún queda mucho por recorrer. En el ámbito comunitario se han dado pequeños pasos pero, en realidad, todavía no se han resuelto de manera unánime en un sentido determinado. Del mismo modo, también se han hecho grandes avances desde organismos internacionales de carácter privado; este es el caso de Amnistía Internacional. Así, Amnistía Internacional, organización no gubernamental (ONG), se ha distinguido desde su fundación en la denuncia y defensa de los presos ideológicos o de conciencia que, aunque ha tardado mucho tiempo en acoger como tales a aquellas personas que son encarceladas en algunos países por no renunciar a su homosexualidad, finalmente lo ha hecho en el Consejo Internacional celebrado la última semana de agosto de 1991 en Yokohama (Japón).

\section{III.2. Tribunal Europeo de Derechos Humanos}

En relación a la homosexualidad, el TEDH ha seguido una línea jurisprudencial diferenciada en dos fases:

En una primera etapa, sólo tuvo ocasión de pronunciarse en el ámbito de la legislación penal; más concretamente, en relación al Reino Unido y a la República de Irlanda, por la existencia de la legislación represiva de las condenas homosexuales, en vigor hasta muy recientemente. Buenos ejemplos son las sentencias conocidas como asunto Dudgeon ${ }^{42}$ y asunto Norris ${ }^{43}$. En ambos, el Tribunal aprovechó para despenalizar determinadas conductas tipificadas por su carácter homosexual, aunque no llegó a la total y plena equiparación entre los heterosexuales y, las relaciones sexuales de este tipo ${ }^{44}$.

En su segunda etapa se aprecia una sustancial evolución en los pronunciamientos del Tribunal en torno a la homosexualidad llegando a exigir algo hasta ahora inédito: la prohibición de discriminación por orientación sexual, equiparando esta causa a las que expresamente están protegidas por recaer sobre ellas

\footnotetext{
${ }^{42}$ STEDH, de 22 de octubre de 1981.

${ }^{43}$ STEDH, de 26 de octubre de 1988.

${ }^{44}$ NAVARRO (1995), p. 53.
} 
una fuerte sospecha de discriminación. Así lo hace en su célebre caso Salgueiro da Mouta Silva ${ }^{45}$, línea jurisprudencial que desde este momento seguirá en sus pronunciamientos.

A partir de aquí, el Tribunal Europeo no sólo ha continuado protegiendo al colectivo homosexual frente a la discriminación, sino que ha comenzado a reconocer ciertos derechos hasta entonces restringidos o limitados para este grupo en un ámbito especialmente sensible como es el familiar. En este ámbito, el Tribunal comenzó reconociendo como familia a la pareja formada por dos personas del mismo sexo, atribuyéndoles ciertos derechos hasta ahora exclusivos de parejas heterosexuales en su asunto Karner ${ }^{46}$. En este asunto, se reconoció el derecho de la pareja supérstite a subrogarse en el contrato de arrendamiento de la vivienda común, antes limitado a parejas formadas por personas de sexo opuesto (en aplicación de la ley estatal), por entender que también aquellos conforman un núcleo familiar. Sin embargo, el detonante de la evolución experimentada por el Tribunal Europeo en cuanto a la defensa del colectivo homosexual, en su interpretación del Convenio de Derechos de la Unión Europea, ha sido respecto al derecho a casarse (artículo 12 del citado Convenio).

Si bien es cierto que no ha llegado a admitir la existencia de un derecho al matrimonio entre personas del mismo sexo como derecho extraído del mencionado Convenio de Derechos, encontramos importantes pronunciamientos en los que puede apreciarse una significativa evolución al respecto. Así, es importante mencionar el asunto C. Goodwin ${ }^{47}$, en la que no se limita a reconocer el derecho al matrimonio de las personas transexuales -en respeto a su derecho a la identidad sexual-, sino que aprovecha este pronunciamiento para advertir que: "no se encuentra motivo alguno que justifique que los transexuales se vean privados en todas las circunstancias del derecho a casarse", evidenciándose así una evolución respecto al concepto tradicional de matrimonio, añadiendo además que: "la incapacidad de una pareja de concebir o criar un hijo no puede en si misma privarle del derecho citado". Este pronunciamiento, además de confirmar el derecho al matrimonio a transexuales, supone la apertura del concepto de matrimonio, hasta entonces limitado entre "hombre y mujer". Esta doctrina, reafirmada en el asunto I. vs. Reino Unido ${ }^{48}$, ha sido seguida desde entonces.

\footnotetext{
${ }^{45}$ STEDH, de 21 de diciembre de 1999.

${ }^{46}$ STEDH, de 24 de julio de 2003.

${ }^{47}$ Stedh, de 11 de julio de 2002.

${ }^{48}$ Stedh, de 11 de junio de 2002.
} 
El más claro ejemplo de esta línea de apertura del concepto de matrimonio ha sido dado recientemente en el asunto EB vs. Francia ${ }^{49}$, en la que el Tribunal condenó a Francia por prohibir la adopción de un menor a una mujer soltera por el hecho de ser lesbiana (teniendo en cuenta que la legislación francesa permite la adopción individual de personas solteras), afirmando que tal discriminación sólo puede justificarse: "por razones particularmente graves y convincentes (...) ahora bien, esas razones no existen en el caso, dado que el derecho francés autoriza la adopción de un niño por un soltero, abriendo asi la vía a la adopción por parte de una persona soltera homosexual". Esta Sentencia es realmente significativa, ya que la adopción es probablemente la cuestión más controvertida relacionada con la orientación sexual, admitiendo que este tipo de adopciones no es perjudicial para el menor.

Sin embargo, a pesar de haber consolidado el derecho al matrimonio de transexuales, e incluso de extender a parejas homosexuales derechos de familia tan importantes como lo es la adopción, el Tribunal no ha llegado a reconocer la existencia del derecho al matrimonio homosexual en Europa como derecho extraído del citado Convenio de Roma. En su reciente asunto S. y K. contra Austria ${ }^{50}$, el Tribunal advirtió que: "(...) en torno a la pregunta de si se debe o no permitir el matrimonio entre personas del mismo sexo, el asunto debe ser resuelto por la reglamentación interna de la ley nacional del pais contratante". Una vez más, el Tribunal deja abierta la posibilidad de extender el matrimonio a nuevos modelos, dejando en esta ocasión en manos de los legisladores estatales la posibilidad de admitir o no el matrimonio entre personas del mismo sexo. Esto, si bien no atribuye la existencia del derecho al matrimonio de manera genérica a todos los ciudadanos europeos, sí admite que este derecho es acorde con lo previsto en el Convenio de Derechos de Europa, pues de lo contrario no se admitiría tal posibilidad por parte de los Estados firmantes del mismo.

Este pronunciamiento aparece en un momento en el que se aprecia una tendencia al reconocimiento de derechos matrimoniales de las parejas homosexuales, bien a través de lo que se denomina "unión civil" (casos como Alemania o Reino Unido) o incluso regulando el "matrimonio". En la actualidad, los países europeos que han reconocido el "matrimonio" homosexual son: Holanda (2001), Bélgica (2003), España (2005), Noruega (2008) y Suecia (2009). Esta situación evidencia la tendencia actual en Europa, pudiendo prever que en un futuro próximo el derecho al matrimonio será reconocido abiertamente entre parejas homosexuales por el Tribunal Europeo de Derechos Humanos.

\footnotetext{
${ }^{49}$ STEDH, de 22 de enero de 2008.

${ }^{50}$ STEDH, de 6 de julio de 2010.
} 


\section{3. Organización Mundial de la Salud}

Durante años se ha catalogado la homosexualidad como enfermedad y a quienes la practicaban, de enfermos por seguir conductas desviadas. Sin embargo, ¿en qué medida afecta la homosexualidad a la salud?, ¡es realmente una desviación, una enfermedad? La dilucidación de estos interrogantes no sólo es importante para la descatalogación de la homosexualidad como enfermedad -algo logrado no hace demasiados años-, sino para probar que quienes optan por una orientación exclusiva homosexual no sufren ningún tipo de trastorno que pueda dar lugar a trato especial ni a restricción de derechos respecto a cualquier pareja heterosexual. No necesitan pues ninguna cura ni tratamiento, sino un igual trato como ciudadanos de un país democrático cuya Constitución reconoce una serie de derechos que se les pueden estar vetando.

Recopilando la evolución que se llevó a cabo a nivel científico, fue en el siglo XIX cuando el concepto de homosexualidad empezó a considerarse como enfermedad mental. A partir de ese momento, la mayoría de los especialistas en la materia así la catalogaron, encargándose a la psiquiatría el tratamiento y rehabilitación de todos los que la practicaban.

No obstante, no fue ésta una corriente unánime en la psiquiatría de la época. Es de destacar la teoría de Freud -padre de la psiquiatría moderna- acerca de la homosexualidad, ya que fue esta la técnica más empleada en la "curación" de homosexuales. En palabras del mismo Freud: "... no es un vicio ni un envilecimiento y no hay razón para tratarla como una enfermedad; la consideramos una variante de la función sexual provocada por un cierto paro en el desarrollo sexual. El perseguir la homosexualidad como un crimen es una gran injusticia y también una crueldad..." 51 .

Es decir, Freud, contra corriente, deja muy claro que la homosexualidad no es una enfermedad pero, al mismo tiempo, dice algo muy importante, que la variante de la función sexual en el homosexual ha sido provocada "por un cierto paro en el desarrollo sexual", con lo que está admitiendo que hay algo anormal en él porque no se ha desarrollado por completo, afirmando que está inacabado, que no ha llegado a su plenitud -sexualmente hablando. Como explica García Valdés, para Freud la homosexualidad no es más que una variante sexual, no constituyendo "ni pecado, ni degeneración o aberración" 52 , quedando pues descartado su tratamiento. En este sentido, el psicoanálisis propuesto como "curación" por Freud tendrá el único fin de restablecer el equilibrio interior del individuo, y es así como hay que entenderlo.

${ }^{51}$ FreUd (1970).

52 García (1981), p. 140. 
Otra figura importante en esta materia fue Gregorio Marañón, también en contra de las tendencias médicas de su época. Contra corriente, no estuvo de acuerdo con la catalogación de la homosexualidad como enfermedad ni con terapias para su curación, considerándola simplemente como una "sexualidad retrasada". El doctor Marañón parte de la idea de que "nadie es hombre absoluto, ni absoluta mujer" 53 , luego se basa en la bisexualidad natural de todo individuo. Por ello, argumenta que la homosexualidad no es una enfermedad sino una sexualidad retrasada.

La orientación homosexual en el ser humano es una tendencia un tanto peculiar en relación con el resto de las especies animales -en las que están comprobadas las prácticas homosexuales-, ya que es la única en la que se da la orientación homosexual exclusiva. Ahora bien, ¿̇tiene la orientación sexual una explicación biológica? Ya hemos estudiado que a lo largo de la historia se ha condenado la homosexualidad, tachándola de "antinatural" y, a raíz de ahí, ha sido calificada como pecado, delito o enfermedad, por considerar que la heterosexualidad es la orientación sexual "normal", quedando la homosexualidad como una alteración o anormalidad de las funciones del ser humano.

No han faltado teorías radicales, como la propuesta por el biólogo Kinsey, centrada en la idea de que el ser exclusivamente heterosexual es el anormal, producto de inhibiciones sociales ${ }^{54}$, mientras que catalogó como normales todos los comportamientos sexuales considerados desviados ${ }^{55}$.

Muchos han sido los estudios científicos realizados en la materia, intentando dar una respuesta que, sin embargo, no han logrado alcanzar de forma clara. Hasta ahora se han dado indicios que muestran que la orientación sexual es, como explica Herrero: "consecuencia de un proceso multifactorial en el cual toman parte tanto los factores biológicos como los factores psicosociales". Estaría determinada pues por factores hormonales, genéticos, físicos o químicos -tanto antes como después del nacimiento- y además, por la experiencia propia del individuo y el ambiente social y cultural que le envuelva. Sin perjuicio de que en la orientación homosexual influya el código genético del individuo, es concluyente el factor ambiental que le rodea. Se trata, por lo tanto, de un doble proceso: genético y ambiental ${ }^{56}$. Consiste en un proceso de interacción entre los genes y las hormonas y otros caracteres de su personalidad. Esto se debe a que los genes y las hormonas no especifican per

\footnotetext{
${ }^{53}$ Marañón (1934), p. 155.

${ }^{54}$ TARASCO (1997), p. 71.

${ }^{55}$ VAN DEN AARDWEg (1997), p. 1309.

${ }^{56}$ Herrero (1997), p. 1324.
} 
se la orientación sexual, pero definen el modo en que un individuo matizará su orientación sexual en relación con su entorno.

Respecto al tratamiento que ha recibido la homosexualidad por parte de la Organización Mundial de la Salud (OMS), podemos decir que, hasta la 10a edición (año 1992) de la Clasificación Internacional de Enfermedades de la Organización Mundial de la Salud, ésta incluía la homosexualidad dentro de las desviaciones y trastornos sexuales.

En la CIE-9 aprobada en 1975 y que estuvo rigiendo desde 1979, fecha de su entrada en vigor, hasta 1992, en que fue sustituida por la CEI-10, se consideró la homosexualidad como una "inclinación o comportamiento sexual anormal". En este aspecto, la OMS ha ido considerablemente rezagada en relación a muchas asociaciones europeas y americanas de psiquiatras y psicólogos, y particularmente a la Asociación de Psiquiatras Americanos (APA), con la que ha mantenido una especial colaboración en los últimos años. En virtud de dicha colaboración, ha experimentado un vuelco la consideración que ha recibido la homosexualidad, desapareciendo en 1992 del listado de la CIE-10, advirtiendo que "la orientación sexual en sí misma no se considera trastorno", y posibilitando el avance hacia la "desmedicalización" de la homosexualidad, de todo lo cual no ha tenido más remedio que hacerse eco la OMS.

\section{CONCLUSIONES}

El tratamiento que la homosexualidad ha recibido por parte de la sociedad, las instituciones e incluso del ordenamiento jurídico, ha experimentado un cambio radical en los últimos años. En pocas décadas se ha pasado de señalar a los homosexuales como pervertidos, depravados o delincuentes, llegando incluso a tipificar penalmente las prácticas homosexuales, a prohibir el trato discriminatorio hacia ellos y a proteger sus derechos.

Tal y como se ha expuesto, la homosexualidad ha sido considerada de maneras muy diferentes en función de la sociedad que tomemos como referencia, si bien en las sociedades modernas ha sido objeto de discriminación y condena hasta época reciente. En el entorno europeo, su aceptación como una opción más elegida libremente por cada cual, legal y respetuosa con el orden público, ha estado directamente relacionada no sólo con la aparición de las Constituciones sino con la interpretación de los derechos dada por el Tribunal de Estrasburgo. De hecho, ha sido éste quien ha condenado a varios Estados europeos por mantener leyes que castigaban la homosexualidad o que diferenciaban de manera injustificada el trato dado a las relaciones homosexuales respecto a las de carácter heterosexual. 
Tras años de aceptación y legalización de la homosexualidad, se ha consolidado la denominada "prohibición de discriminación por orientación sexual", en virtud de la que se exige un trato igual con independencia de la orientación sexual. Así, más allá de la igualdad de trato en los más diversos ámbitos, se exige el reconocimiento de ciertos derechos, antes reservados a los heterosexuales. En la actualidad, y en gran medida gracias a la labor del Tribunal Europeo de Derechos Humanos, se reconoce y se protege el derecho de los homosexuales a formar una familia en pareja o incluso de adoptar hijos. Y, respecto al derecho al matrimonio, aunque no se ha llegado a reconocer tal derecho a nivel europeo, se respeta la voluntad de cada Estado para configurarlo de manera libre, siendo varios los países europeos que han aprobado el derecho al matrimonio entre personas del mismo sexo.

En definitiva, la evolución experimentada en el tratamiento social y jurídico de la homosexualidad ha sido por fortuna, insospechada, aventurando incluso el reconocimiento de un derecho europeo al matrimonio entre homosexuales en un futuro próximo, siguiendo la trayectoria del Tribunal Europeo.

\section{Bibliografía}

Arnalte, A. (2003): Redada de violetas. La represión de los homosexuales durante el franquismo (Madrid, Ed. La Esfera de los Libros), 300.

BRUNDAGE, J.A. (2000): La ley, el sexo y la sociedad cristiana en la España medieval (México D.F., Fondo de Cultura Económica), 669.

Boswell, J. (1998): Cristianismo, tolerancia social y homosexualidad (Barcelona, Biblioteca Atajos), 407.

Boswell, J. (1996, a): Les unions de même sexe dans l'Europe antique et médiévale (París, Fayard), 540.

Boswell, J. (1996, b): Las bodas de la semejanza. Uniones entre personas del mimo sexo en la Europa premoderna (Barcelona, Muchnik Editores S.A.), 641.

Duby, G. (1990): El amor en la Edad Media y otros ensayos (Madrid, Alianza Editorial), 228.

ERIBON, D. (2000): Identidades. Reflexiones sobre la cuestión gay (Barcelona, Bellatierra), 144.

ERIBON, D. (2001): Reflexiones sobre la cuestión gay (Barcelona, Ed. Anagrama), 528. ERIBON, D. (2005): Por ese instante frágil...: reflexiones sobre el matrimonio homosexual (Barcelona, Ed. Bellaterra), 235.

Freud, S. (1970): Tres ensayos sobre la Teoría sexual (Madrid, Alianza Editorial), 231. GarCía, A. (1981): Historia y presente de la homosexualidad (Madrid, Ediciones Akal), 376. 
GonZÁleZ, E. (1976): Represión sexual, dominación social (Madrid, Ediciones Akal), 272.

Herrero, M.T. (1997): "Teorías neurobiológicas sobre el origen de la homosexualidad”, en Cuadernos de Bioética (No 32, vol. 8), pp. 1322-1343.

MARAÑón, G. (1934): Ensayos sobre la vida sexual (Madrid, Ed. Biblioteca Nueva), 239.

MarTíneZ, L. (2005): La homosexualidad y el matrimonio (Madrid, Ediciones Académicas), 393.

Navarro, R. (1995): Matrimonio y derecho (Madrid, Tecnos), 133.

SASLOW, J.M. (1989): Ganimedes y el Renacimiento. La homosexualidad en el arte y en la sociedad (Madrid, Ed. Nerea), 269.

Sauquillo, A. (1986): Federico García Lorca y la cultura de la homosexualidad. Lorca, Dali, Cernuda, Gil-Albert, Prados y la voz silenciada del amor homosexual (Estocolmo, Stockholms Universitet), 383.

Sergent, B. (1986): La homosexualidad en la mitología griega (Barcelona, Ed. Alta Fulla), 297.

SORIANo, M.A. (2005): La marginación homosexual en la España de la Transición (Madrid, Egales), 222.

Tomás y Valiente, F. (1969): El Derecho Penal de la Monarquía Absoluta. Siglos XVI, XVII y XVIII (Madrid, Tecnos), 479.

TomÁs y Valiente, F. (2000): "El crimen y el pecado contra natura", en Orientaciones, Revista de Homosexualidad (No 1), pp. 105-128.

Tarasco, M. (1997): "Consideraciones sobre la influencia del raporte Kinsey", en Cuadernos de bioética (No 32, vol. 8), pp. 1.385-1397.

Van Den Aardweg, G.J.M. (1997): "La homosexualidad, una neurosis sexual (y como se impone al mundo una ideología trastornada)", en Cuadernos de Bioética (No 32, vol. 8), pp. 1309-1321.

Van Den Aardweg, G.J.M. (1997): Homosexualidad y esperanza. Terapia y curación en la experiencia de un psicólogo (Pamplona, Eunsa-Ed. Universidad Navarra), 157.

\section{REFERENCIAS JURISPRUDENCIALES: \\ Jurisprudencia del Tribunal Supremo Español (TS):}

STS de 5 de noviembre de 1974.

STS de 20de diciembre de 1966.

STS de 20 de diciembre de 1966. 
STS de 30 de noviembre de 1953.

STS de 27 de octubre de 1965.

Jurisprudencia del Tribunal Europeo de Derechos Humanos (TEDH):

STEDH de 26 de octubre de 1988.

STEDH de 22 de octubre de 1981.

STEDH de 26 de octubre de 1988.

STEDH de 21 de diciembre de 1999.

STEDH de 24 de julio de 2003.

STEDH de 11 de julio de 2002.

SETDH de 11 de julio de 2002.

STEDH de 22 de enero de 2008.

STEDH de 6 de julio de 2010. 
